\title{
Lower and Middle Palaeolithic Mortuary Behaviours and the Origins of Ritual Burial João Zilhão
}

\section{INTRODUCTION}

Although we now know that the site of the 1856 discovery of the eponymous remains - the Kleine Feldhofer Grotte, in the Neander valley - was in all likelihood a place of burial (Schmitz 2006), the fact that Neanderthals buried their dead was not scientifically established until 1908, at the Bouffia Boneval, one of the caves in the La Chapelle-aux-Saints complex of Palaeolithic localities (Figures 3.I and 3.2). A near-complete skeleton, the 'old man', was found here, lying inside a $0.30 \mathrm{~m}$ deep, approximately $\mathrm{I} .50 \times \mathrm{I} .00 \mathrm{~m}$ depression of the marly bedrock whose morphology (roughly rectangular, with straight walls and a flat bottom) indicated that it had been deliberately dug for the disposal of the corpse (Boule I9I3).

A string of similar discoveries followed and, with those made at Mt. Carmel in the I930s (McCown \& Keith 1939), the practice became documented also among the anatomically modern peoples that briefly occupied the Near East during the last interglacial. As a result, the notion that burial was a cultural innovation of the Middle Palaeolithic, appearing in the archaeological record some I00,000 years ago and irrespective of human taxonomic affinities, became commonplace in the field of palaeoanthropology until the late i98os. However, in the framework of the 'Eve Hypothesis' and the 'Human Revolution' paradigm, whose internal consistency required the removal of Neanderthals from the range of human-ness in both biology and behaviour, that notion became the object of intensive scrutiny. Although, at first, questions were raised with the Neanderthals specifically in mind, the logic of the argument made it almost inevitable that such questions eventually extended to the Middle Palaeolithic in general (Gargett I989, I999).

As two Israeli scholars were quick to point out, the ultimate implications of the sceptical argument were that burial should be considered unproven even as late in prehistory as the Natufian (Belfer-Cohen \& Hovers I992). However, this elegant refutation by reductio ad absurdum of the burial deniers' position did not suffice to put the issue to rest, as shown by interpretations derived from a recent re-analysis of the context of the child skeleton excavated in 196I at Roc-de-Marsal (Dordogne, France: Sandgathe et al. 20II). At first glance, the new evidence can be construed as supporting the proposition that, in this particular instance, deliberate burial is not confirmed. But this conclusion need not imply that a similar verdict become the null hypothesis for the interpretation of all the other instances of Neanderthal burial currently known. In fact, recent work at La Chapelle-aux-Saints verified the veracity of the original accounts, via rediscovery and re-exposure of the artificial burial pit described by the excavators (Rendu et al. 20I4).

In truth, the key questions underpinning these controversies had all been asked and answered by Leroi-Gourhan (1964) more than two decades before the onset of the late I980s-early I990s debate. If the preservation of Middle Palaeolithic articulated skeletons results from the operation of entirely natural processes and does not require purposeful protection to be accounted for, and if the large number of such finds known from this period is not a reflection of the emergence of intentional burial, how then do we explain (a) why identical instances of articulated human skeletons remain unknown from earlier levels of similar (if not the same) sites, and (b) why do we not find identical instances of articulated skeletons of 

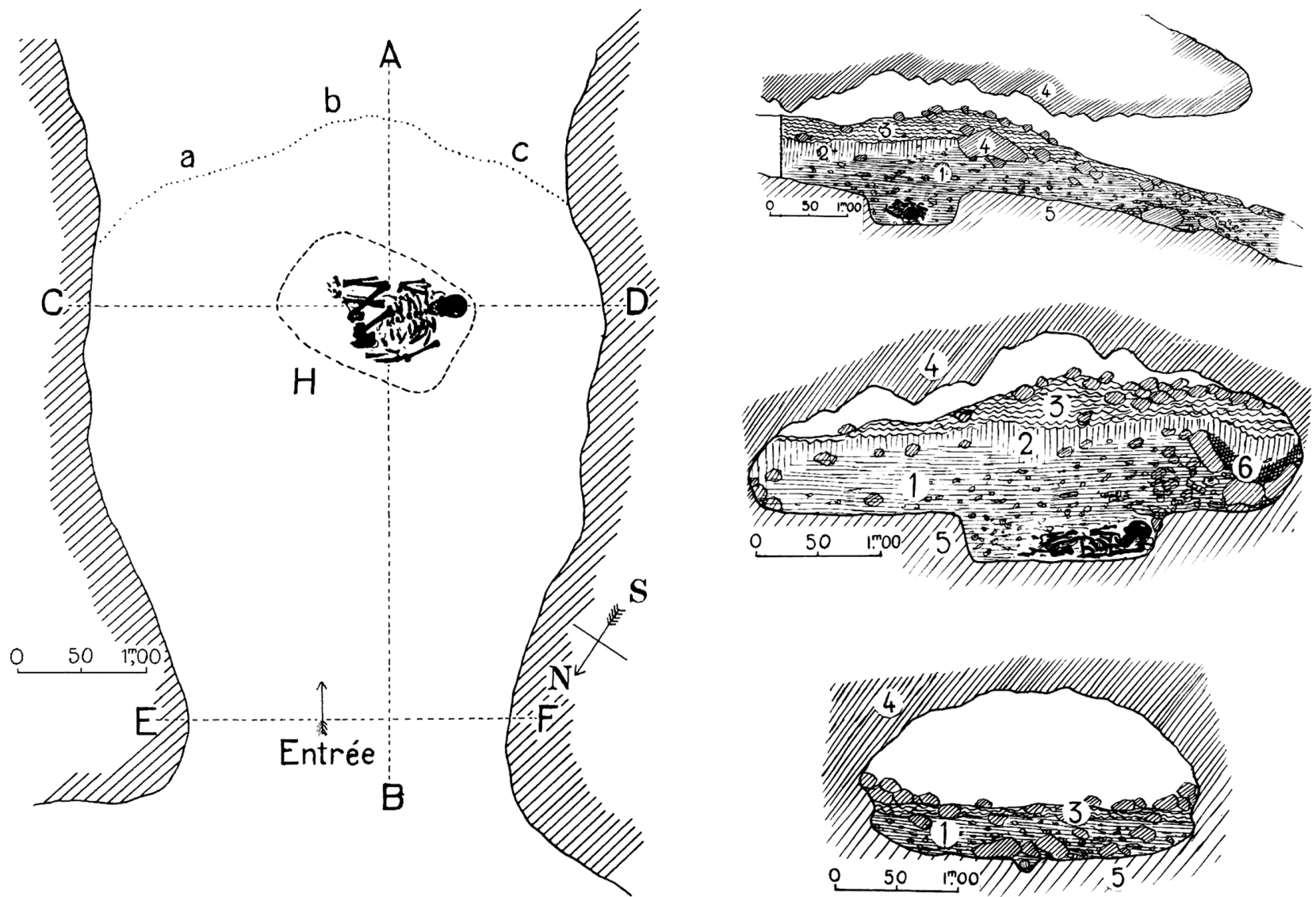

Figure 3.I. The Bouffia Boneval at La Chapelle-aux-Saints.

Left: Plan of the site, with outline of burial pit $(\mathrm{H})$, limits of excavation (a, b, c), and different stratigraphic profiles (AB, CD, and EF). Right: Stratigraphic profiles: I, archaeological level; 2, clay; 3 , loose clayey sandy earth; 4, rocky vault and collapsed boulders; 5 , natural bedrock (limestone and greenish clays of the Infralias); 6, burnt earth level.

After Boule I9I3: figs. 4-7.

other cave dwelling animals (foxes, wolves, hyenas, etc.) in the same deposits? Moreover, how do we explain that the La Ferrassie 6 individual, the skeleton of a three- to five-year-old child, was found inside a deep pit covered by a limestone slab whose inferior face was decorated with cup marks? What natural process would have produced the marks, and what is the probability that among the large number of slabs that fall from the roof and walls of any rock-shelter, this particular one would, uniquely among those found in the site's Mousterian levels, feature such marks and, by chance alone, happen to end up lying exactly atop the pit and with the cup-marked side facing down?

Deniers of burial in the Middle Palaeolithic in general, or only among Neanderthals in particular, have never been able to answer these questions. That is why I believe there is no point in reverting to the issue from a 'Did they do it or not?' perspective, or in repeating the descriptions of the evidence upon which the notion that 'They did do it' is based. A number of such overviews exist (e.g., Binant I99I; Defleur 1993), with a most recent addition being Paul Pettitt's (20II), which, additionally, has the merit of framing the practice in an evolutionary model of the relationship between humans and death. Pettitt's proposition is that the emergence of burial in the Middle Palaeolithic is preceded by a long period during which (a) behaviours seen, in a manner that is not qualitatively distinct, among our closest living relatives, the chimpanzees (and, therefore, presumably going back to a common Miocene ancestor), are elaborated in distinctive human ways (e.g., via the use of stone tools); (b) new behaviours emerge that reflect the beginnings of a symbolic appropriation of place; and (c) such new behaviours underpin the eventual emergence, much later in prehistory, of the repeated, long-term use of dedicated sites for the disposal of the dead, that is, of cemeteries. 

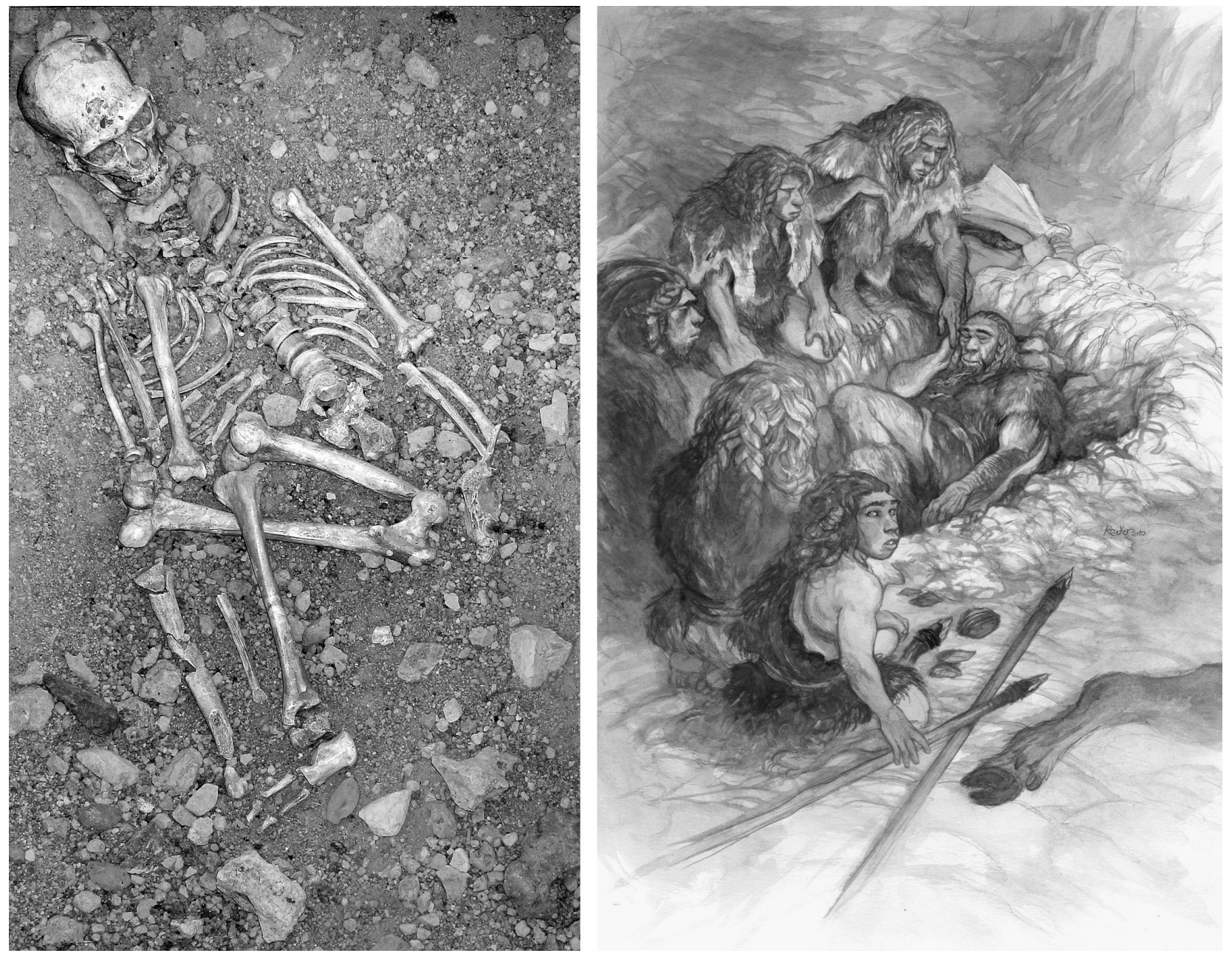

Figure 3.2. The Bouffia Boneval burial.

Left: As reconstructed in the Musée de l'homme de Néandertal at La Chapelle aux Saints.

Right: The associated funeral ceremony as imagined by artist Emmanuel Roudier.

Reproduced with permission of the author.

In the following, I will dissociate Pettitt's model, which provides a very useful device for the assessment of the evidence, from his account of how, when, and where different types of mortuary activity first can be seen in the archaeological record of the Lower and the Middle Palaeolithic. The account is entirely plausible, and my intention here is not to contradict it but simply to suggest that, where some aspects of the issue are concerned, alternative interpretations are at least equally plausible. Ultimately, the key question I want to address is the following: does the apparent emergence of burial ca. IOO,000 years ago result from the long-term, cumulative development of ever more sophisticated approaches to death and the dead, and does such development perhaps have cognitive underpinnings at some level? Or is such an emergence more easily amenable to description as a punctuated process, where the broad coincidence in time with the first appearance of body painting, personal ornaments, and object decoration reflects a common underlying cause, the complexification of social relationships?

\section{TYPES OF MORTUARY ACTIVITY}

At one end of the range, the evidence compiled by Pettitt (2OII, 8-IO) is very persuasive: curation ("the carrying around of the dead, either of an entire corpse, or of preserved body parts'), morbidity ('an enquiring concern with the injured, the diseased or dead body'), Cronos compulsions ('to dismember, injure or consume parts of the bodies of one's conspecifics'; Figure 3.3), and 


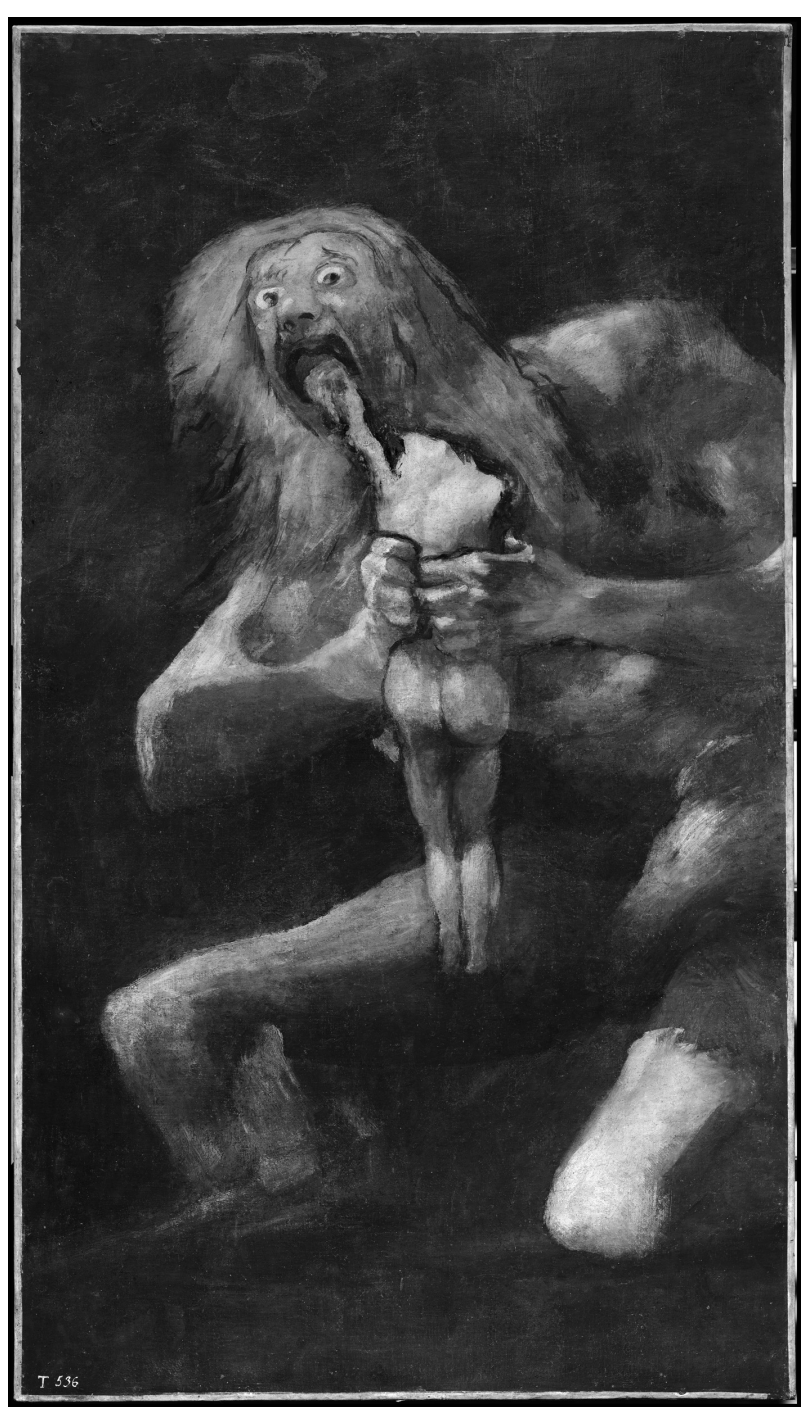

Figure 3.3. Goya's Saturn [Greek Cronos] Devouring His Child. (C) Madrid, Museo Nacional del Prado

abandonment ('the simple act of leaving a helpless individual to die') are all part of the behavioural repertoire of the chimpanzees. At the other end of the range, it is also clear that (a) formal burial ('the creation of an artificial place for the purposes of containing a corpse') is unknown before ca. I00,000 years ago, and (b) it is not until the very end of the Upper Pleistocene that, strictly speaking, the cemetery category ('places given over in the main or entirely to the dead, with little or no evidence of settlement'), as documented in northern Africa after some 20,000 years ago, can appropriately be applied to known burial sites.

This pattern leaves the period of about four million years separating the Middle Palaeolithic from the first australopithecines open to the question of whether four 'intermediate' types of mortuary behaviour, ones that are documented in humans in the present but not among chimpanzees, could have emerged during that long interval of time. These types (Pettitt 20II, 8-IO) are (a) the production and circulation of relics ('corpses and body parts ... accorded social agency and used accordingly'); (b) structured abandonment ('the deliberate placement of a corpse at a certain point in the landscape'); (c) funerary caching ('the structured deposition of a corpse, or parts of a corpse, in a chosen place, without modification of that place,' differing from structured abandonment in that 'the place is given meaning beyond prosaic concerns such as corpse protection'); and (d) cairn covering ('the creation of a cairn - a pile of stones - over a corpse').

As acknowledged by Pettitt, however, cairn covering is essentially similar to simple inhumation and thus can be considered for all practical, archaeological purposes as a variant of formal burial. On the other hand, the recognition both of relics and of funerary caching depend on factors (agency and meaning) that are rarely preserved and for which it is not easy to derive indisputable archaeological correlates, and even less so in the material culture circumstances of the Lower Palaeolithic period. Therefore, the answerable part of my earlier question can be reduced to the following: can we recognise structured abandonment in the archaeological and human palaeontological record of australopithecines and early humans?

\section{STRUCTURED ABANDONMENT}

As well illustrated by Pettitt's (2OII, 42-5) discussion of the $A$. afarensis AL-333 locality, the case for structured abandonment essentially revolves around the twin issues of numbers and concentration. In rejecting the hypothesis that this fossil accumulation could have resulted from a catastrophic depositional event, Pettitt's instrumental argument is that the hominin bone assemblage is composed of at least thirteen individuals, including adults and infants, spread over only about seven metres. Presumably, therefore, it is because they fail to combine concentration and quantity that Pettitt does not count as structured abandonment instances where the remains of a single individual were retrieved in similar depositional environments from the same broad geographical region namely, the I.8 million-year-old $H$. erectus adolescent known as the Nariokotome boy (Brown et al. 1985), or the > I00,000-year-old H. sapiens adult Omo I (Fleagle et al. 2008). And there is indeed good reason not to do 
so, as an Italian example, the Altamura Neanderthal, well illustrates (Vacca \& Pesce Delfino 2004).

The Altamura fossil is a stalagmite-encased partial skeleton of an adult male preserved in a recess located sixty metres inward from the presumed point of entry to the cave system - an eight-metre-deep vertical shaft known as the Lamalunga Cave (Figure 3.4). The contextual evidence indicates that a single, complete articulated skeleton originally existed, and that the current arrangement (and representation) of body parts results from in situ disarticulation and collapse, which generated the observed spread, subsequently fossilised by calcite deposition. Given its location, tucked away in the deep karst, and completeness, this skeleton would therefore appear to be a prima facie candidate for the status of funerary cache body deposition in a place so out of the way that its choice for the purpose of structured abandonment surely reflects the special meaning assigned to it. However, it is also readily apparent that we could be dealing instead with the remains of an accidental death, where an individual fell through the shaft, and surviving that fall but unable to climb back up, would have become trapped deep inside the cave system, in complete darkness, while attempting to find an alternative way out. Failing to do so, he would eventually have frozen, or starved, to death.

This example shows why numbers are important in the argument, at least from the perspective of parsimony. If, as in the AL-333 case, this recess of the Lamalunga Cave had contained the remains of thirteen individuals, including adults and children, the probability that the accumulation resulted from the chance repetition of the same story over a relatively long stretch of time would be vanishingly small - although the accident could have occurred more than once, why would the victims, presumably unprepared for what befell them and thus devoid of lighting to find their way underground, always end up dying in the exact same spot as their predecessors? Had a significant number of individuals been found, and with similar completeness, alongside the Altamura Man, we would therefore have to acknowledge that the accumulation resulted from intentional mortuary activity. The deposition of corpses directly on the ground surface deep inside a cave is, after all, a type of funerary behaviour well documented in the European Neolithic, the Portuguese cave site of Algar do Bonsanto being a near-pristine example thereof (Duarte I998). In this speculative scenario, one would be logically led to infer that the origins of the behaviour would go back to Neanderthal times and to such hypothetical Altamura-type burial caves. And that is exactly the issue raised by the Sima de los Huesos, one of the localities of the Sierra de Atapuerca (Burgos, Spain) complex of Palaeolithic sites.

\section{THE SIMA DE LOS HUESOS}

The Sima de los Huesos ( $\mathrm{SH}$ ) is a constrained space (circa twenty-seven square metres) accessed via a ramp located at the bottom of a thirteen-metre-deep shaft opening from a larger chamber above, the Sala de las Oseras (named after the bear bones and hibernation features therein); today, this chamber is reached via a speleological route starting at the Cueva del Silo, but it once must have been connected to the exterior in ways that were practical for the bears. The SH deposits are of Middle Pleistocene age, and contain the remains of at least twenty-eight individuals of Neanderthal or ante-Neanderthal affinities and a number of carnivores (Figure 3.5): bear, Ursus deningeri (minimum number of individuals $[\mathrm{MNI}]=\mathrm{I} 76$ ), fox $(\mathrm{MNI}=2 \mathrm{I})$, wolf $(\mathrm{MNI}=\mathrm{I})$, lion $(\mathrm{MNI}=3)$, panther $(\mathrm{MNI}=\mathrm{I})$, wild cat $(\mathrm{MNI}=\mathrm{I}), \operatorname{lynx}(\mathrm{MNI}=\mathrm{I})$, marten $(\mathrm{MNI}=\mathrm{I})$, weasel $(\mathrm{MNI}=2)$, polecat $(\mathrm{MNI}=3)$ and badger $(\mathrm{MNI}=\mathrm{I})$. No herbivore remains were found, and the single artefact is a biface whose Acheulean typology agrees with the chronology suggested by palaeontology (Andrews \& Fernández-Jalvo I997; García et al. I997; Fernández-Jalvo \& Andrews 200I; García \& Arsuaga 20I I; Bermúdez de Castro et al. 2004; Carbonell \& Mosquera 2006; Martinón-Torres et al. 2012).

Bermúdez de Castro et al. (2004) interpret this accumulation as a two-step process. The first would have consisted of a relatively short event (geologically speaking) during which the human remains were taken to the $\mathrm{SH}$ space. The second step was the deposition of the bear remains, which, despite some mixing, tend to be found above the human ones. Among the latter, all body parts are represented, and the age profile is strongly biased in favour of adolescents and young adults: ages at death are between eleven and twenty in 64 percent of the cases, a single individual is less than ten, and only I percent are more than thirty-five years old. This age profile is considered to be non-attritional and used to argue against the assemblage of human bones being the result of the operation of non-cultural processes (e.g., natural trapping). The rationale underlying the argument is that such non-cultural processes would have culled the different age classes in proportions identical to those extant among the living but that such proportionality is not observed at the SH. That is why Bermúdez de Castro et al. also 

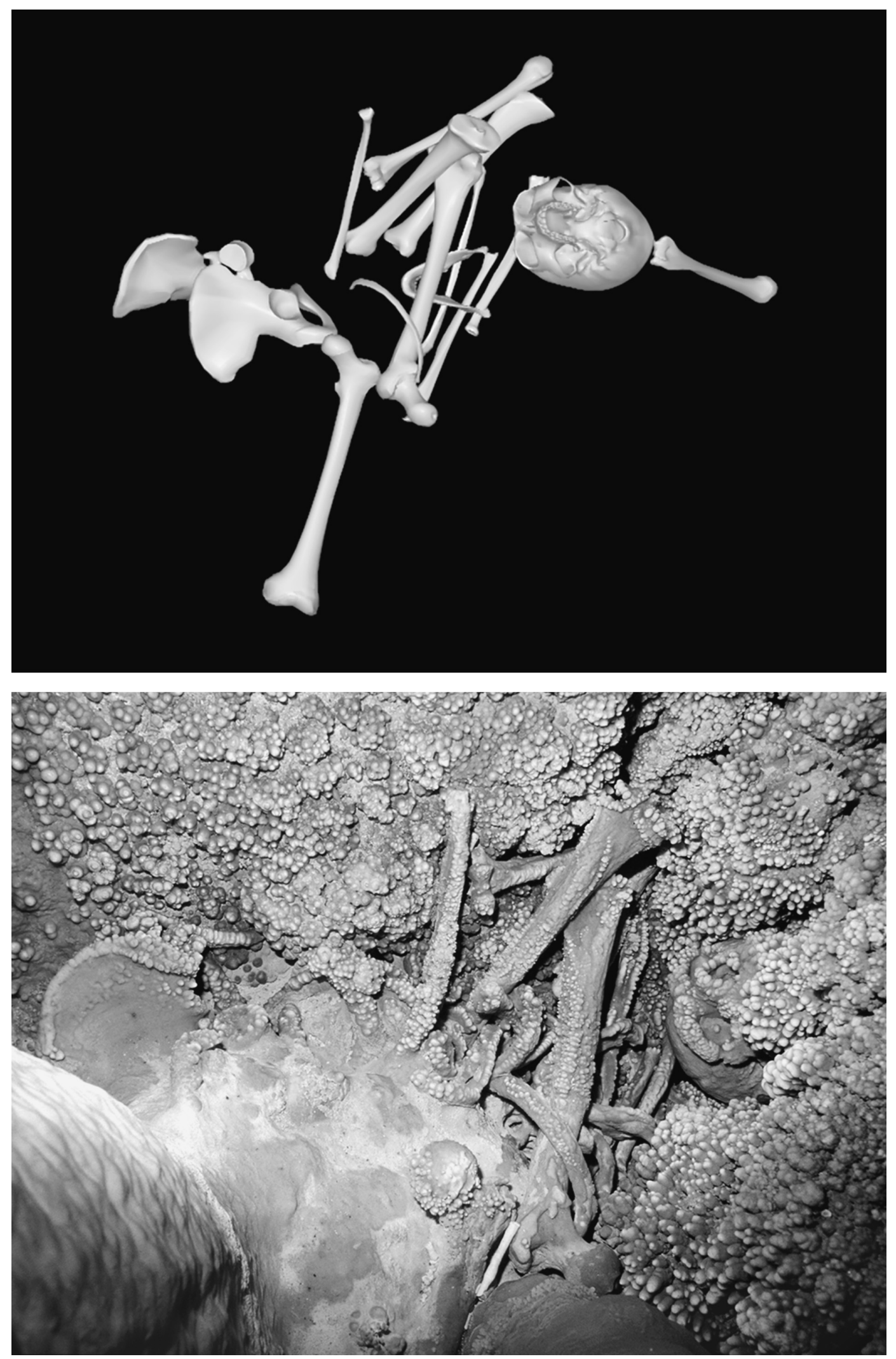

Figure 3.4. Altamura Man.

Above: Virtual, three-dimensional reconstruction of the topographic distribution of the bones.

Below: Photographic view of the calcite-covered remains.

AfterVacca \& Pesce Delfino (2004, figs. I, 4). 

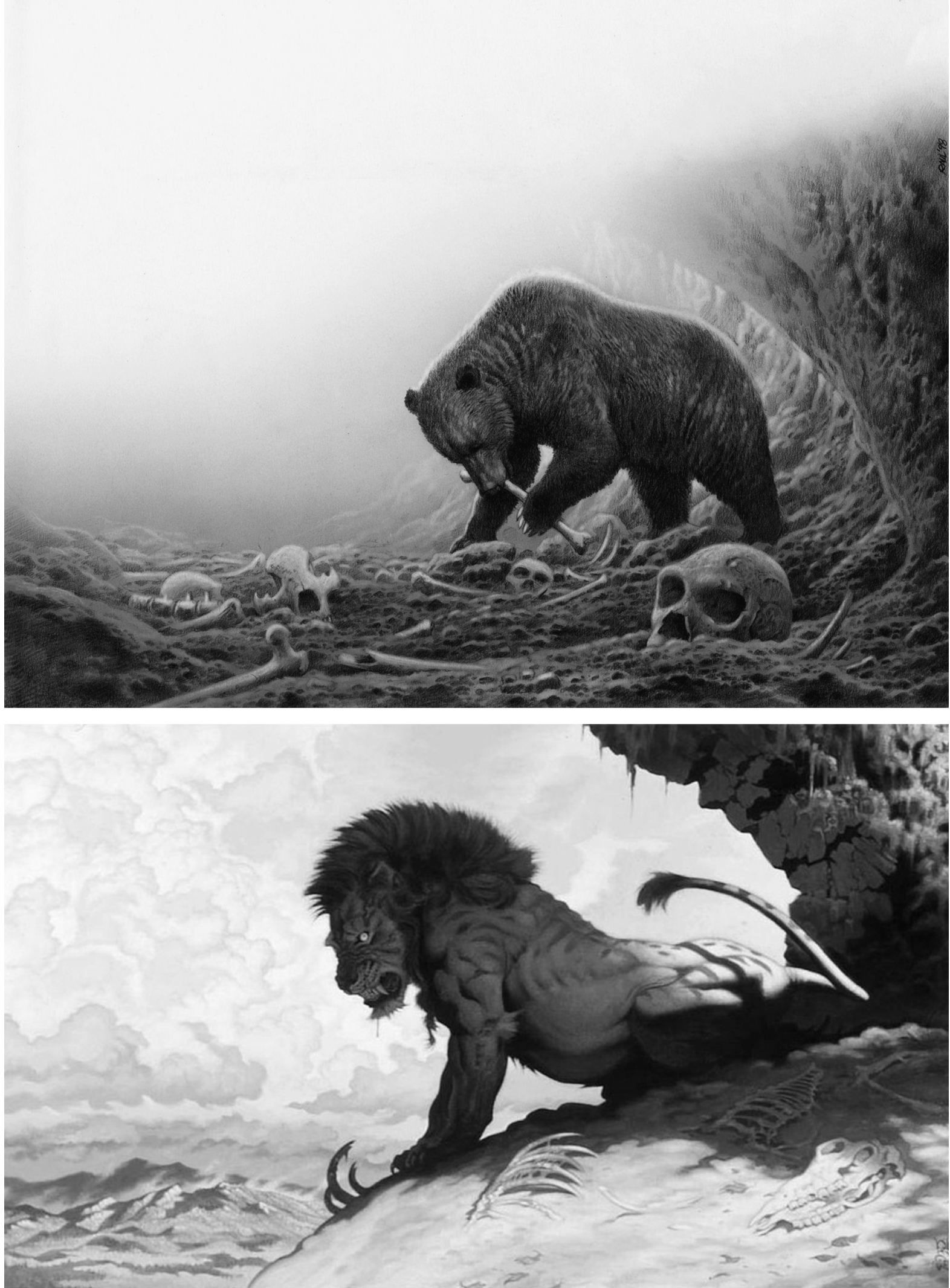

Figure 3.5. The large carnivore competitors of the Sierra de Atapuerca Middle Pleistocene humans.

Top: Cave bear (Ursus deningeri, an ancestor of Ursus spelaeus). Copyright Raúl Martín/Madrid Scientific Films, used by kind permission. Bottom: cave lion. Copyright François Miville-Deschênes; used by kind permission. 
find it difficult to accept that the human bone accumulation could have resulted from a single catastrophic event, along the lines, for instance, of Bocquet-Appel and Arsuaga's (I999) hypothesis (see later discussion).

Bermúdez de Castro et al. (2004) conclude, therefore, that only a culturally mediated bias can explain the SH pattern. Specifically, they propose that the site functioned as a place for the dead, that is, in terms of Pettitt's model, as a place of structured deposition. Pettitt himself does not exclude this possibility, although, following the taphonomic arguments of Andrews and Fernández-Jalvo (1997) and Fernández-Jalvo and Andrews (200I), he rejects the specific modus operandi suggested by Bermúdez de Castro et al. (2004) - that the SH would be the place of primary accumulation of the human bones, the assemblage resulting from the use of the shaft above the ramp as a locus for the ritual dumping of dead bodies. In agreement with Fernández-Jalvo and Andrews (200I), Pettitt's view is that the SH represents instead the final resting place of the human remains, which would have undergone a bumpy taphonomic history with a number of intermediate steps involving carnivore activity (some $50 \%$ of the bones feature tooth marks inflicted by both foxes and a large felid) and transport by geological processes from elsewhere in the system.

Where exactly in the system might such an original locus of deposition be located is a thorny issue. Under the assumption that the activity of bears and humans was effectively contemporaneous (albeit, by necessity, alternating), the absence of bear-inflicted marks on the human bones implies rejection of the hypothesis that such a locus was the Sala de las Oseras, where bear hibernation is attested, where the $\mathrm{SH}$ bear remains probably originate, and where this bear activity implies the existence of a nowadays-collapsed entrance. In this scenario, an alternative point of entry would have to be considered; however, the topography of the system suggests that none exists.

Keeping in mind the absence of bear marks on the human bones and the stratigraphy of the SH deposits, a simple solution to this apparent conundrum can be envisaged. It consists of a site formation process whereby the human remains accumulated in an initial phase, one during which bears were not yet using the site; the straightforward transport path for those remains being the shaft above the SH ramp, the simplest hypothesis for the location of the original deposit would thus be the chamber where the shaft opens, that is, the Sala de las Oseras. Under these premises, the Sala de las Oseras could be construed indeed as a locus formally designated for the disposal of the dead. The implications are important: in Pettitt's (20II, 55) words, 'when this point is arrived at, the landscape has become dichotomised: places of life, and places of the dead.'

I agree with Pettitt that one cannot reject the possibility that the SH represents such a watershed in the prehistory of death, with corroboration provided by other, albeit later, Palaeolithic localities featuring accumulations of the same order of magnitude in terms of number of individuals. A case in point is Krapina, in Croatia, where, however, the cause of the accumulation is also controversial. Bocquet-Appel and Arsuaga (1999) relate it to a catastrophic event along lines that would also apply to the SH: 'a segment of the age-pyramid whose members, at first sight, are physically resistant and mobile ... normally able to run away from the impact area of a catastrophe' would have 'under severe privation ... stopped in the shelter exhausted' and eventually died there. Supporting Bocquet-Appel and Arsuaga's case, the Krapina human MNI, age profile, and body part representation (Trinkaus I985, 1995) are indeed similar to those seen at the $\mathrm{SH}$, which, thus, would be exceptional only in the degree of concentration of the finds; moreover, the Krapina body part representation pattern matches that of Middle Palaeolithic burials, suggesting that the human bones entered the site as complete corpses. This observation, however, has led most commentators to interpret the Krapina assemblage as originally formed by intentional burial, whether primary or secondary (the latter based on controversial cut mark evidence; Russell I987; Orschiedt 2008), not as resulting from a catastrophic event.

On the other hand, even if, in terms of body part representation and age at death, Krapina and the $\mathrm{SH}$ are indeed similar, they also differ in that Krapina is the unquestionable primary locus of deposition of the remains, and, more importantly, in that it is a habitation site. These features align Krapina with the evidence from coeval sites of the Near East (Qafzeh and Skhul), opening up the possibility that the practice of interring the dead in the places of the living was widespread in the Greater Mediterranean of the time, and this irrespective of the humans involved being anatomically modern or Neanderthal (Shanidar being another example, if the earliest of its burials are of last interglacial age, as hypothesised by Zilhão \& Trinkaus 2002).

The Near Eastern sites do not seem to display the same bias towards adolescents and young adults seen in the $\mathrm{SH}$ sample, but a dearth of older adults is a general feature of 
Palaeolithic samples up until Gravettian times (Trinkaus I995, 20II). At the SH, only the near-absence of infants and children would therefore remain problematic and possibly a reflection of cultural bias, not populational mortality patterns. Post-depositional preferential destruction of the more fragile bones of immature individuals could explain their under-representation: this is explicitly suggested by Andrews and Fernández-Jalvo (1997) for the SH and could conceivably be the case at Krapina too (here, however, the under-representation of children disappears if a 'total sample' MNI is retained instead of the 'associated dentition' MNI used in Trinkaus' I995 palaeodemographic calculations). In short, under differential preservation premises the $\mathrm{SH}$ assemblage might be construed as attritional, and the biases underpinning the need to invoke cultural agency in the explanation of the site's formation process would be no more.

However, if post-depositional loss of the more fragile elements of the skeleton is a viable explanation for the Krapina pattern, it is less clear that it works at the $\mathrm{SH}$, because of the preservation of very delicate skeletal parts (e.g., ear bones: Bermúdez de Castro et al. 2004) seen among the adults. The notion that the age profile of the $\mathrm{SH}$ assemblage is a genuine reflection of the original thanatocoenosis thus seems to be warranted. If we reject catastrophe, this apparently leaves no option but to revert to the notion that the accumulation reflects mortuary behaviour - either in the form imagined by Bermúdez de Castro et al. (2004) or, following Andrews and Fernández-Jalvo (1997) and Pettitt, as structured abandonment elsewhere at the site. In order to be consistent with the evidence, however, the notion requires special clauses, namely, that such mortuary behaviour was rather selective, with at least four distinct possibilities being conceivable:

(a) The first is that only adolescents and young adults were deemed worthy of funerary treatment, the other age classes being dealt with at the time of death in a different way. One might then speculate as to why; for example, perhaps the death of infants and old people was 'natural' (or 'to be expected'), while the death of individuals in their prime was 'unnatural' and the cause of much grief, as it hindered the group's production and reproduction potential.

(b) The second possibility is that this specific locus was a place dedicated to the disposal of the bodies of prime age individuals, the other age classes being disposed of elsewhere at sites likewise specifically dedicated to each of those classes (e.g., at places for infants and children and at places for the elders).

(c) A third possibility, given that a significant number of the SH individuals display some form of pathology, is that the place represented a locus for the disposal of prime age individuals killed by disease; as pointed out by Pettitt, however, the pathologies observed could not have been a direct cause of death, and those affected by them seem to have survived for long after such health problems began to develop.

(d) Fourth, bearing in mind Trinkaus' $(1995,2011)$ mortality estimates and a pattern that is very apparent much later (Zilhão \& Trinkaus 2002; Zilhão 2005), it is possible that the absence of older individuals simply reflects the general dearth of aged people in human populations prior to the mid-Upper Palaeolithic, and that infants and children were, as a rule, deemed unworthy of any form of funerary treatment (as seems to be the case in the Gravettian, albeit with notable exceptions, e.g. the Krems-Wachtberg burials: Einwögerer et al. 2006).

The need to explore these different alternatives only arises, however, if we concede that the $\mathrm{SH}$ age profile is neither catastrophic nor attritional, but, by implication, culturally biased instead. As discussed previously, Bocquet-Appel and Arsuaga (1999) argue in favour of a catastrophe, but their hypothesis (a) requires the unlikely combination of a number of very special circumstances and (b) is in contradiction with the pattern of differential preservation apparent in the human remains (Fernández-Jalvo \& Andrews 200I), which counters the notion that the bone accumulation represents a single event, one whereby all the individuals therein would have died at the same time. That the age profile is not attritional, on the other hand, rests on the assumption that the accumulation should reflect an ordinary mortality curve, that is, one in which the most vulnerable age groups, the very young and the very old, are best represented, not the observed opposite. But is this assumption warranted? I contend that, if we introduce into the picture issues of gender- and age-based division of labour and structured mobility across the landscape, it is not. Put another way, I contend that the $\mathrm{SH}$ accumulation can indeed be construed as a random sample of the human population that constituted the site's potential catchment of fossils.

The first point to bear in mind in this regard is that the Sierra de Atapuerca rises to circa one thousand metres in the middle of the northern Meseta, a region of 
continental climate where, today, the average annual temperature is $10^{\circ} \mathrm{C}$ and the average low is at or below freezing from December to March. Under Ice Age conditions, and based on Last Glacial Maximum values for Iberia as a whole, temperatures would have been at least $10^{\circ} \mathrm{C}$ colder. The exact chronology of the $\mathrm{SH}$ deposit in the Middle Pleistocene remains controversial, but the composition of the carnivore assemblage suggests that it was formed at a time when the site's broader environmental setting consisted of a savannah-like open woodland; in addition, the pollen spectra from samples of the clay matrix of the $\mathrm{SH}$ fossils provide evidence for the presence of pine, beech, and birch - and, hence, of stands of boreal forest - in the site's catchment (García \& Arsuaga 20II). This evidence is consistent with stadial rather than interstadial conditions.

Therefore, the assumption that, as among ethnographically documented hunter-gatherers living under similar conditions, the territory adjacent to the $\mathrm{SH}$ (or at least the Sierra de Atapuerca itself, if not the surrounding plateau too) would have been utilised in logistical fashion, perhaps seasonally, seems entirely reasonable. If so, we are then envisaging a scenario where (a) the human frequentation of the Sierra would have mostly consisted of hunting parties composed of individuals in their prime, and (b) only this subset of the population would therefore have been available for random culling by whatever environmental factors capable of causing human deaths were in existence - sudden disease, large carnivore predation, hunting or travel accidents, and so on. Even if such events had been very rare, given enough time they would have resulted in a substantial death toll; at one per century, for instance, less than three millennia would suffice to produce the MNI recorded at the $\mathrm{SH}$.

The originally published sex profile of the assemblage of human remains, based on tooth size variation, is in apparent contradiction with this hypothesis. The method used resulted in an estimate that twelve males, eight females, and eight individuals of indeterminate sex were represented in the sample, and such a high percentage of females $(40 \%)$ might not be expected at a death site related to the activity of hunting parties operating in cold environments. However, more recent work suggests that the SH sample is in fact mostly made up of males. For instance, among a sample of twenty-seven long bones sufficiently complete for measurement and discriminant analysis, only six $(22 \%)$ were diagnosed as belonging to females (Carretero et al. 20I2).

As the overall body part representation indicates that the $\mathrm{SH}$ assemblage derives from complete corpses and there is no reason to suppose that female bones would have preserved less well or be subject to some other form of bias, it seems reasonable to infer that these long bone percentages are a genuine reflection of the sample's sex ratio. This is corroborated by the fact that the two sufficiently complete fossils for which the diagnosis of sex is secure - the pathological skull nicknamed 'Miguelón' and the complete pelvis nicknamed 'Elvis' - are of males (Arsuaga et al. 1993, 1999). Even though any sexing of the sample carries significant uncertainty, the picture arising from these data is one of a thanatocoenosis primarily made up of adolescent and prime adult males - and all the more so if we bear in mind the possibility that some of the 'female' long bones could correspond to shorter, more gracile males.

This 'hunting party death trap' hypothesis explains both the particular age profile of the SH human bones and the evidence concerning their reported sex ratio, but in and of itself does not suffice to explain two other features of the fossil assemblage as a whole: its concentration in a restricted and secluded space, and the absence of herbivores. Brief consideration of a case study from 40,000 years ago, the Peştera cu Oase, in Romania (Zilhão et al. 2007; Trinkaus et al. 20I3), sheds some light on these features too.

\section{THE PEŞTERA CU OASE MODEL}

The 2004-5 Oase excavation project was designed for the recovery of the missing parts of two individuals discovered as surface finds during speleological surveys and for the explanation of their context and depositional history. Where the latter is concerned, the basic question was, Does the presence of a mandible and a cranium in the middle of a jumble of cave bear bones located deep inside the karst, in a passage with no known communication with the exterior (Figure 3.6), result from entirely natural accumulation processes, or must some form of human agency have been involved? In short, a question that is much the same as that posed by the $\mathrm{SH}$.

The results obtained at the end of the project were that the bone jumble corresponded to a palimpsest subsuming a number of depositional moments (Figure 3.7):

(a) Initially (Episodes 1 and 2), the place functioned as a bear hibernation den, and in $>99$ percent of cases bones are of cave bears that died there;

(b) Subsequently, an opening to an adjacent sinkhole formed along one of the walls of the Sala Mandibulei, 

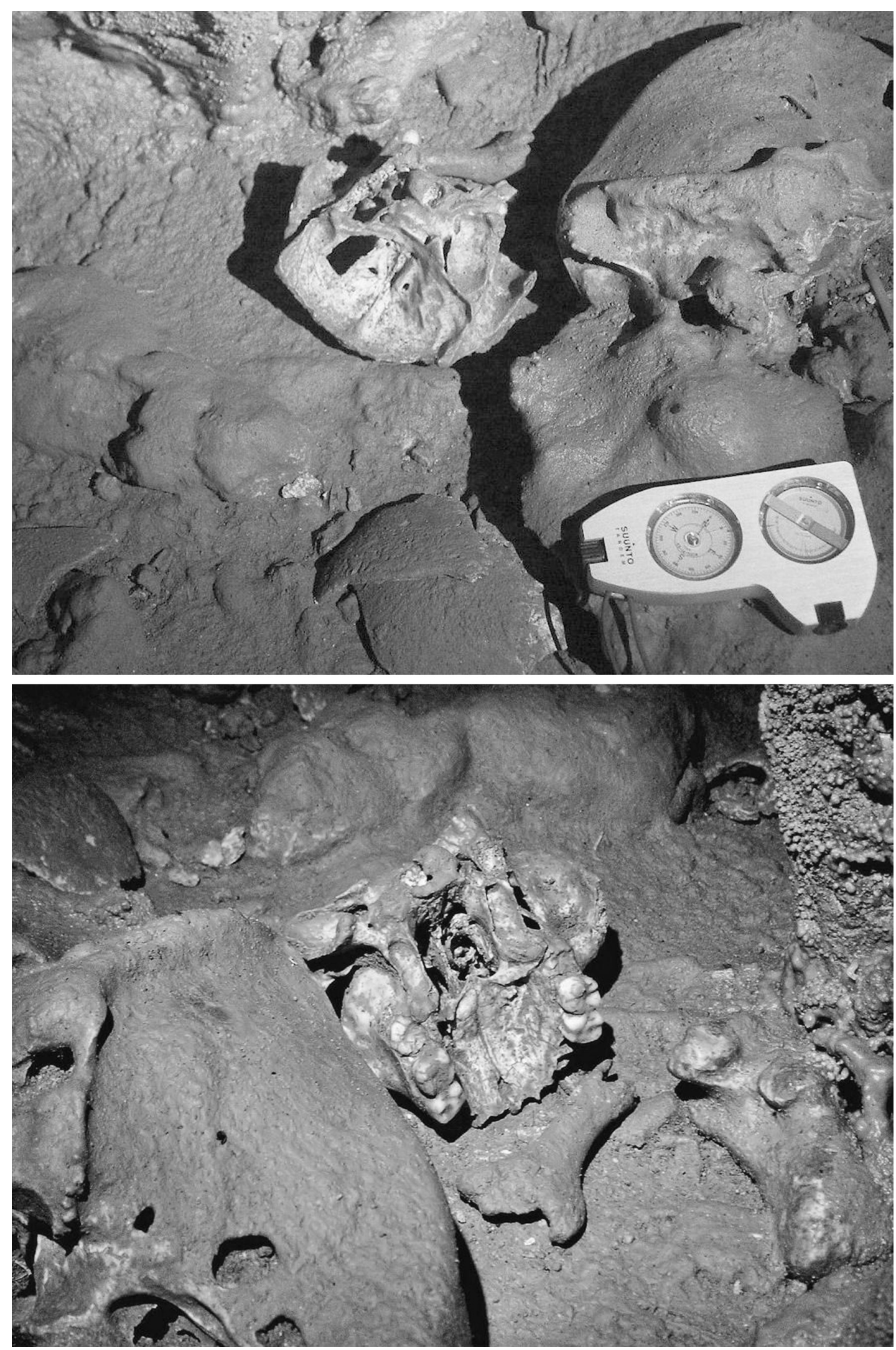

Figure 3.6. Two views of the Oase 2 cranium in situ.

After Trinkaus et al. (2013). 


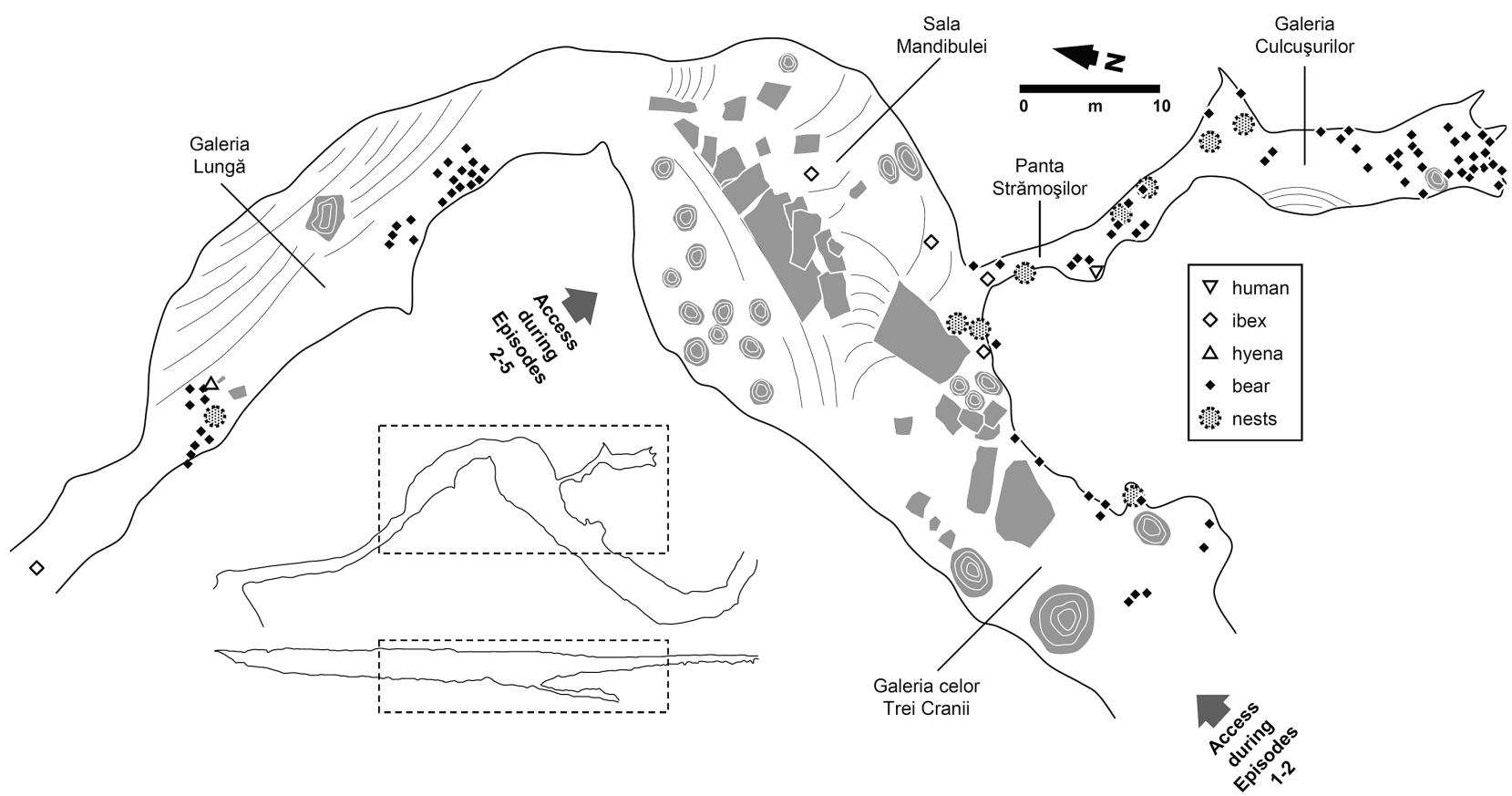

Figure 3.7. The Oase passages, with indication of their names, of the position of the cranial remains from different species, and of former entrances.

After Trinkaus et al. (2013).

which ceased to be appropriate for bear denning because of the new temperature and lighting conditions; besides those of smaller mammals (e.g., foxes), the accumulated bones are now those of the principal new occupants, hyenas and wolves, and of the latter's prey, cervids (Episodes 3 and 4);

(c) The gradual fill-up of the different entrances to the Oase passages eventually impeded use by the larger carnivores, and, reflecting the change of the surrounding environment from boreal forest to alpine desert, the new middle-to-large mammal bone material added to the Sala Mandibulei surface palimpsest consisted exclusively of non-cave-dwelling species namely ibex, probably the remains of individuals that died while taking up shelter in the adjacent sinkhole (Episode 5);

(d) The growth of a massive stalagmite curtain sealed the connection between the Sala Mandibulei and the exokarst, and, but for minor changes generated by small-scale geological and biological agency (e.g., run-off and small mammal burrowing), the chamber regained the appearance it had when bears last hibernated in the cave (Episode 6).

The human remains entered this system at the beginning of Episode 5 and via the adjacent sinkhole. No evidence was found that living humans had ever been inside the cave system before its discovery by speleologists in 2002, and no artefacts (e.g., tools or objects of personal ornamentation) were found in the excavated deposits; therefore, no case can be made for the accumulation of these remains to have resulted from human agency, either as formal burial, funerary caching, or structured abandonment. This, plus the taphomony of the human remains, led the Oase project to conclude that the parsimonious explanation for the presence of the fossils in a chamber located deep inside the karst resided in the operation of purely natural processes. A conceivable scenario is one comprising the following steps: (I) random death by accident or natural causes; (2) burial under winter snow; (3) spring melt water transport of partly mummified bodies to the bottom of a sinkhole; (4) primarily gravitydriven, small scale dispersal of body parts across the surface of the adjacent passages of the endokarst; (5) burial under sediments introduced by the same mechanism; (6) re-exposure, via small mammal burrowing, atop the stabilised surface extant since the blocking of the connections to the outside; and (7) further dispersal of individual pieces of the skeleton to the eventual points of discovery by the continued activity of small mammals, low-energy water flow, and gravity. 
This example shows that a number of the SH's features are not as exceptional as at first glance they seem to be. At Oase, in fact, we also see (a) a human thanatocoenosis mostly made up of late adolescents and young adults (exclusively so, albeit the sample is too small for the pattern to be taken as an age profile in any statistically meaningful sense), (b) a concentration of this material in an out-of-the-way place discovered by speleologists that can only be accessed via demanding speleological routes, and (c) an associated faunal assemblage forming a highly impoverished reflection of the mammal communities extant at macro-regional level. The only significant differences between these two examples lie in the smaller size of the Oase human bone assemblage, in that it is composed of skull parts only, and in that, alongside those of carnivores, remains of cervids (with a MNI of 3 calculated on the basis of skeletal parts, morphology, and ancient DNA [aDNA]) also accumulated at the site during Episode 3.

The difference in body part representation, however, may be a simple consequence of spatial sampling, as the $\mathrm{SH}$ is a $27-\mathrm{m}^{2}$ area that has been the object of extensive, continuous excavation over most of its area for two decades now. In contrast, the Sala Mandibulei of the Oase system - the inferred locus of deposition of not only the Oase I mandible but also the Oase 2 cranium, post-depositionally displaced onto the surface of the adjacent Panta Strămoşilor - is a $>300-\mathrm{m}^{2}$ chamber where no excavation has been carried out. Moreover, the taphonomy of the Oase human remains suggests that associated post-crania were also present when this material first entered the system.

Where the difference in assemblage size is concerned, it could well be a simple consequence of temporal sampling, as the $\mathrm{SH}$ accumulation conceivably represents several millennia, while the two Oase individuals were broadly contemporaneous. The contextual evidence further indicates that the window of opportunity for the accumulation of the Oase humans was a rather short one, as all the other components of the palimpsest are either much earlier (at least four to five thousand years for the large carnivores and the deer) or much later (at least ten to twelve thousand years for the ibex).

Accepting these explanations for the differences, the $\mathrm{SH}$ assemblage can thus be construed as Oase multiplied by a factor of IO, with such a multiplication resulting from the operation of time alone. Let us posit, as implied by its use for bear hibernation, that the Galeria de las Oseras/ Sima de los Huesos system was once connected to the exterior by a cave or sinkhole entrance (or a number of them) at present plugged by collapse or sedimentary fill. Acting as a funnel, as such karst formations always do, these entrances could have functioned as sampling devices, entrapping at the time of death the active life going about the area of their catchment at one end, and concentrating it in a restricted space at the other end. If such active life consisted primarily of large carnivores and humans competing for the same prey or the same shelter space, and if the humans in question were young and adult male hunters in their prime, then the accumulation of 80 percent or more of the $\mathrm{SH}$ sample is accounted for by entirely natural processes and there is no need to invoke human agency to explain it. And that Middle Pleistocene Atapuerca was a setting where humans and large felids indeed engaged in direct confrontation is otherwise proven by the finding of cut-marked bones of a single lion individual in a habitation context of the site complex - level TD io-I of the Gran Dolina locality (Blasco et al. 20Io).

In such a scenario, the dearth (or absence) of herbivores can be explained by the nature of the immediate setting if, at the time of formation of the $\mathrm{SH}$ assemblage, the Sierra was covered by boreal forest, as suggested by the pollen evidence. Such forests are notoriously poor in herbivore taxa - restricted to moose and reindeer in northern latitudes, and to deer in more southerly ones - and it should come as no surprise that none would have been sampled in the manner described previously if the carnivores involved did not include species whose behaviour includes the transport of body parts (whether skeletonised or not) to a den. In Oase's second phase, the only large carnivores present besides bear, whose death is denning or hibernation related and occurred in situ, are hyena and wolf, and their activity can account for the deer found in the fossil assemblage because they are well-known bone accumulators. At the $\mathrm{SH}$, however, the other large carnivores are mostly felids, which consume their prey at the kill site and do not transport bones back to the den, and the single Canis sp. individual represented in the assemblage could well have ended up at the site in much the same manner as the humans (that is, as a result of inter-predator competition).

Duly accounting for local karst topography, stratigraphy of the bone accumulation, time depth involved, palaeoenvironmental setting, human social organisation, large carnivore behaviour, and the insights gained from consideration of the Oase case, there is, therefore, 

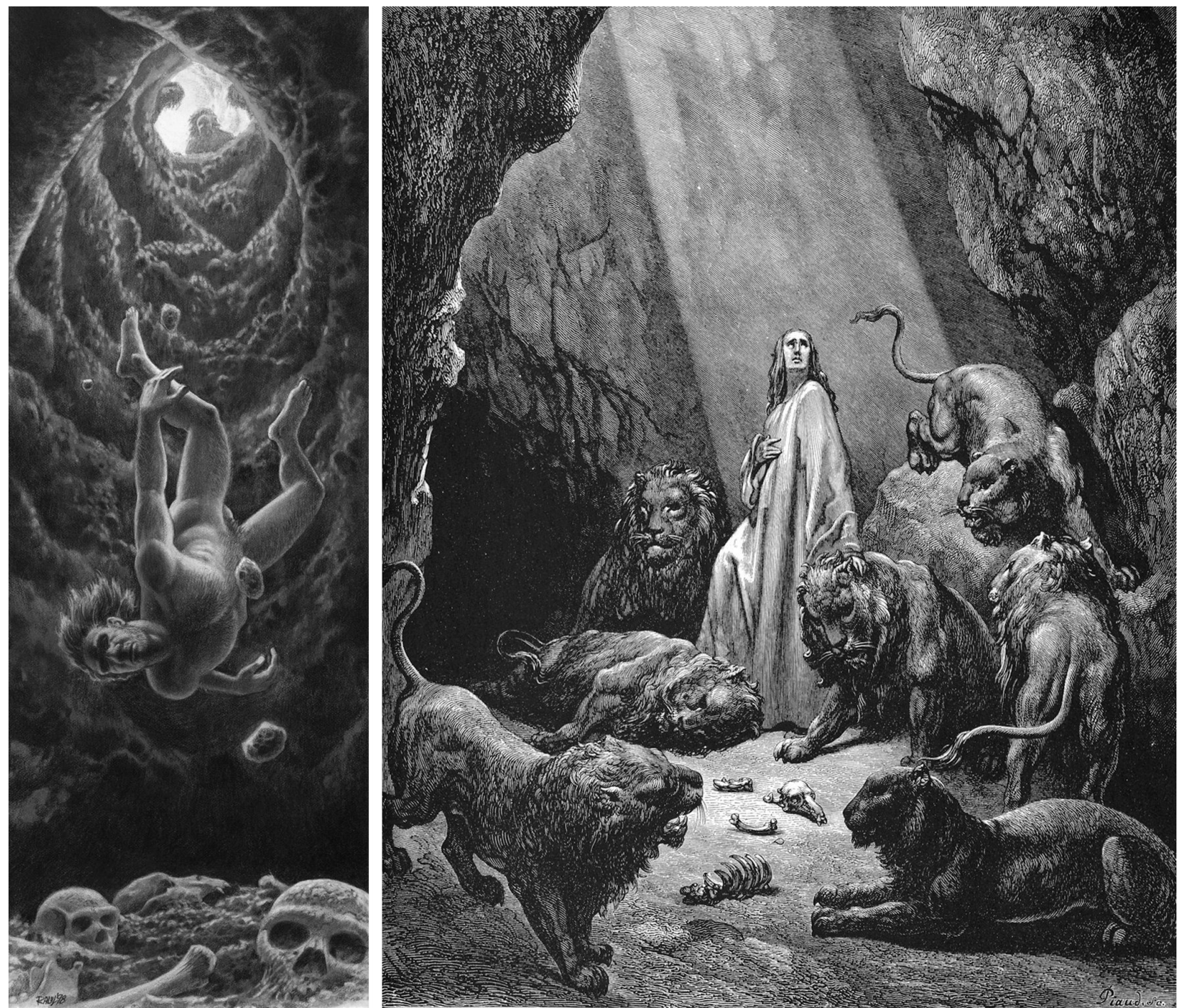

Figure 3.8. Humans in the Sima de los Huesos.

Left: Like Alice, down the hole? Copyright Raúl Martín/Madrid Scientific Films; used by kind permission.

Right: Like Daniel, in the Lions' Den (after G. Doré).

no need to invoke cultural agency to explain the apparently unique features of the $\mathrm{SH}$ assemblage of human fossils (Figure 3.8). An alternative site formation process can plausibly be envisaged along the lines of the following two-phase model. Initially, the entrance or entrances leading from the exokarst to the Sala de las Oseras functioned as lion denning areas, ones where the accumulation of human remains would reflect the natural entrapping of hunters killed by accident or disease, or the infrequent but fatal outcomes of a number of close encounters between the lions and members of hunting parties primarily composed of adolescents and young adults; then, via the shaft uniting the Sala de las Oseras with the SH, and after an interval during which they were exposed to gnawing by foxes, the human and felid bones were displaced by solifluction and debris flow to the eventual palaeontological find spot. At a later point in time, the Sala de las Oseras became a bear den, perhaps because of changes in the topography of the network of underground passages - for instance, the blocking of adjacent entrances could have transformed that chamber from a twilight into a deeply interior, completely dark space. This would have made the Sala de las Oseras inaccessible for large felids but optimal for bear hibernation. Subsequently, in a second iteration of the displacement mechanism, the remains of the bears that died while 
hibernating in the Sala de las Oseras would have followed the same route to the same place, where they would have ended up overlying the human bone bed previously formed - as is indeed the observed stratigraphic configuration of the $\mathrm{SH}$ deposits.

\section{THE EMER GENCE OF FORMAL BURIAL}

Altamura Man and the Sima de los Huesos are the two instances of Lower and Middle Palaeolithic accumulations of human remains whose formation processes are, at first glance, the most difficult to grasp and the most amenable to invoke intentional deposition of the structured abandonment or funerary caching types. If natural processes can explain them, then such processes in all likelihood explain other cases for which the evidence is less clear-cut. A good example is Pontnewydd Cave (Wales), which yielded the remains of a minimum of five and possibly as many as fifteen Neanderthals. The chronology is also Middle Pleistocene, the numbers are of the same order of magnitude as at the $\mathrm{SH}$, and the sex and age ratios are similar: 'mostly male and under 20 years of age' (Pettitt 20II, 55). This is exactly what one would expect in the framework of a model of random cave and sinkhole sampling of the logistical hunters subset of human populations living off periglacial environments. Such a model further explains the difference in composition between the $\mathrm{SH}$ and the burial thanatocoenosis of the Middle Palaeolithic in general. The latter features a normal mortality profile (Zilhão \& Trinkaus 2002; Zilhão 2005), indicating that differentiation by age class was absent from Neanderthal burial custom and weakening the case for the practice to underpin the lack of infants and children in the SH human bone assemblage.

The 'hunting party death trap' model also provides a consistent null hypothesis to assess 'off-site' instances of human bone accumulations from later Palaeolithic times, a case in point being the Aurignacian early modern humans from Mladeč (Teschler-Nicola 2006). As at the $\mathrm{SH}$, one child is present, but the other five recognisable individuals are all prime adults or late adolescents, of which three are clearly male. The presence of females is possible but on the basis of cranial and pelvic evidence that is not really conclusive: 'Mladeč I and Mladeč 2 are quite different females, with so many masculine features that in the absence of the males they could well have been considered male specimens' (Wolpoff 2002, 744); 'the precise form of the Mladeč 2I preauricular sulcus may occur in males or females as a result of tension on the sacroiliac ligaments (a paraglenoid sulcus), but the depth of the sulcus suggests the bony resorption through pregnancy that is diagnostic of its being female ... the degree of openness of the greater sciatic notch would be very unusual in a male pelvis' (Trinkaus et al. 2006, 4I5).

Whatever the case was at Mladeč, the Cussac example shows that funerary caching in the deep karst was indeed present in the Upper Palaeolithic (Aujoulat et al. 2007). This observation thus prompts the question of why no similar, unambiguous instances from earlier periods have so far been found. Given the previous discussion, the parsimonious explanation would be that the emergence of the practice, even though apparently less 'complex', post-dates that of formal burial, the latter being in fact the earliest type of funerary behaviour in human prehistory.

If we accept this conclusion, we then have to face another interesting aspect of early mortuary practice that formal burial first occurs at sites routinely used for habitation (e.g., Tabun, Skhul, Qafzeh, Shanidar, La Ferrassie), not at ones where habitation was infrequent or non-existent. In later prehistoric contexts (e.g., the Mesolithic shell-middens of Scandinavia and Portugal), the consensus interpretation of the close association between settlement and interment is that it stands for sedentism or, at least, a long-term focus of residential activity in a restricted number of specific places. I suggest we should think in much the same way about Palaeolithic sites that were inhabited durably and intensively and where burial occurred on multiple occasions. Seen from this perspective, the emergence of burial is therefore but a manifestation in the realm of mortuary behaviour of a broader process, that of the crossing of a significant threshold in the territoriality of human groups, resulting from demographic growth triggered by adaptive success and, ultimately, by technological progress.

Much the same can be and has been suggested as the explanation for the emergence of personal ornamentation and of stylistic variation in stone tools, which both begin to be seen at about the same time as formal burial (d'Errico et al. 2003; Zilhão 2007). I would argue that this evidence forms a consistent pattern and cannot be dismissed as simple coincidence. In short, paraphrasing Gilman's (1984) seminal paper on the emergence of what some call 'modern human behaviour', I would argue that, over a period of several millennia between the end of the penultimate glacial period and the beginning of the last, that is, over a period that can be construed as long in the historical time scale but that was actually rather 
short in evolutionary terms, a sort of 'Middle Palaeolithic Revolution' occurred. Formal burial was part of the cultural package underpinning the crossing of this watershed.

\section{CONCLUSION}

It is certainly possible that the Herto cranial remains were retained as relics (White et al. 2003), and that some of the fossil human remains from Lower and Middle Pleistocene localities reflect a form of structured abandonment. However, the perforated human teeth of the Aurignacian (Henry-Gambier et al. 2004) remain the earliest unambiguous evidence that human skeletal parts were manipulated and used in a symbolic manner; 'Cronos compulsions' of the kind seen among chimpanzees suffice to explain all other earlier instances of body part manipulation, with the use of stone tools, evidenced by cut marks, simply representing the distinctively human form of the different behaviours subsumed in the category. Likewise, natural processes can account for these periods' human bone accumulations of apparently inexplicable location, abundance, and concentration, provided we duly consider two important factors that are often overlooked in the discussion of such instances: time depth of the accumulation and organisational structure of the source group (with AL-333 remaining perhaps the single exception where the operation of natural mechanisms alone could be insufficient).

If we accept the preceding, then it is not until the beginning of the Middle Palaeolithic that a kind of mortuary behaviour unseen among our closest living relatives first appears in the record - and that behaviour is formal burial. A corollary of this recognition is that apparently less complex types of funerary activity, such as body caching, which are only securely documented in the Upper Palaeolithic, may represent materially simplified but in fact conceptually more elaborate versions of burial, not an intermediate or 'transitional' kind of behaviour bridging the gap in the treatment of death that exists between apes and humans in geological time as much as in biological space.

I believe that the conclusions to be drawn from the preceding are of a demographic and social nature, and I would certainly argue against the search for cognitive underpinnings as a productive research strategy to obtain an explanation for the 'Middle Palaeolithic Revolution' proposed earlier. As in Renfrew's (I996) 'sapient paradox', the fact that a given behaviour is externalised in an archaeologically visible manner must be taken to imply a long pre-existence of the corresponding capacity. It is quite possible, therefore, that concepts about death, the dead, and an afterlife that were essentially the same as those seen among present-day humans existed in Lower Palaeolithic minds and societies before the emergence of formal burial - but, as pointed out by Pettitt, if their behavioural correlates were of the let-the-bodies-ofthe-dead-flow-downriver-to-eternity type, no material evidence of the practice will have survived.

If such concepts did exist, it seems unlikely, however, that any and all forms of Lower Palaeolithic mortuary behaviour were of an archaeologically invisible nature; it would be entirely to be expected that other forms of mortuary behaviour existed alongside. For instance, to establish a link between death and survival, life, and afterlife, early humans could have celebrated their dead by burning them at the places where successful communal hunts occurred, and, if so, we might find sites of the La Borde (Brugal \& Jaubert 1996) or Côte de St.-Brelade (Scott 1980) type but where the remains of aurochs or rhino would have become combined in a palimpsest with the remains of such funerary pyres. But we do not have such sites. It is in this respect that I find particularly telling in two respects the specific form - burial - under which mortuary behaviour of a kind that is novel in the ape lineage first can be seen in the archaeological record: its association with residential localities; and its timing, ca. IOO,000 years ago, broadly coincident with the emergence of other forms of symbolic behaviour amenable to leaving a durable imprint in the archaeological record.

In short, the point I want to make here is not that forms of mortuary behaviour that are specifically human and fundamentally distinct from those seen among chimps did not exist in the Lower Palaeolithic. Rather, my points are simply that

(1) If they existed, no secure evidence to that effect has so far been found.

(2) When we do have such evidence is at the beginning of the Middle Palaeolithic and what we then do see formal burial - is of greater elaboration than would be expected in the framework of a model of gradual evolution from simpler to more complex forms of mortuary behaviour.

(3) The emergence of formal burial is broadly coincident with that of body painting, personal ornamentation, and object decoration, forming a package that is more amenable to social- or demography-based explanations than to cognitive- or human taxonomy-based ones. 
(4) The association of formal burial with residential localities is strongly suggestive of the existence of a link between the emergence of the practice and that of formalised territoriality - that is, of ethnicity and ethnic boundedness.

(5) Rather than signifying the crossing of thresholds in the capacity for symbolic thinking or the acquisition of 'religiosity', the emergence of formal burial in the Middle Palaeolithic seems instead to consist of using the dead for the staking of a claim - by associating them with long-term residential use of certain sites, formal burial can be taken as signposting that 'our ancestors lie here; this is our place.'

\section{ACKNOWLEDGEMENTS}

The 2004-5 field work at Oase was funded by Washington University in Saint Louis, the Wenner-Gren Foundation for Anthropological Research, the Leakey Foundation, the National Science Foundation, the Instituto Português de Arqueologia, the Institut royal des Sciences naturelles de Belgique, and the Romanian National Council for Academic Research. The images in Figure 3.4 are by E. Vacca; copyright, Università degli Studi di Bari and Soprintendenza Archeologica della Puglia; used by kind permission. The image of the bear in Figure 3.5 is copyright Raúl Martín/Madrid Scientific Films; used by kind permission. The image of the cave lion in Figure 3.5 is copyright François Miville-Deschênes, used by kind permission, and inspired by J.-H. Rosny Aîné's novels. The left image in Figure 3.8 is copyright Raúl Martín/ Madrid Scientific Films; used by kind permission. The right image in Figure 3.8 is by G. Dore in the Illustrated English Bible of I866. My thoughts on the Sima de los Huesos have greatly benefited from years of debating them in class with students, to whom I owe to a great extent their elaboration to the present form. Discussions with Alfonso Arribas, Paul Bahn, Paul Pettitt, Erik Trinkaus, and Josefina Zapata throughout preparation of a draft were of great help in focusing my arguments. To all I am grateful. As usual, any errors or omissions are my own only.

\section{REFERENCES}

Andrews, P. \& Y. Fernández-Jalvo, I997. Surface modifications of the Sima de los Huesos fossil humans. Journal of Human Evolution 33, I9I-2I7.

Arsuaga, J.-L., C. Lorenzo, J. M. Carretero, A. Gracia, I. Martínez, N. García, J.-M. Bermúdez de Castro \& E. Carbonell, I999.
A complete human pelvis from the Middle Pleistocene of Spain. Nature 399, 266-8.

Arsuaga, J.-L., I. Martínez, A. Gracia, J. M. Carretero \& E. Carbonell, I993. Three new human skulls from the Sima de los Huesos Middle Pleistocene site in Sierra de Atapuerca, Spain. Nature 362, 534-7.

Aujoulat, N., J.-M. Geneste, C. Archambeau, M. Delluc, H. Duday \& D. Gambier, 2007. La grotte ornée de Cussac (Dordogne): Observations liminaires. Paléo I3, 9-I8.

Belfer-Cohen, A. \& E. Hovers, I992. In the eye of the beholder: Mousterian and Natufian burials in the Levant. Current Anthropology 33, 463-7I.

Bermúdez de Castro, J. M., M. Martinón-Torres, E. Carbonell, S. Sarmiento, A. Rosas, J. van der Made \& M. Lozano, 2004. The Atapuerca sites and their contribution to the knowledge of human evolution in Europe. Evolutionary Anthropology I3, 25-4I.

Binant, P., I99I. Les sépultures du Paléolithique. Paris: Éditions Errance.

Blasco, R., J. Rosell, J. L. Arsuaga, J. M. Bermúdez de Castro \& E. Carbonell, 20I0. The hunted hunter: The capture of a lion (Panthera leo fossilis) at the Gran Dolina site, Sierra de Atapuerca, Spain. Journal of Archaeological Science 37, 205 I-60.

Bocquet-Appel, J. P. \& J.-L. Arsuaga, I999. Age distribution of hominid samples at Atapuerca $(\mathrm{SH})$ and Krapina could indicate accumulation by catastrophe. Journal of Archaeological Science 26, 327-38.

Boule, M., I9I3. L'homme fossile de La Chapelle-aux-Saints. Paris: Masson.

Brown, F., J. Harris, R. Leakey \& A. Walker, I985. Early Homo erectus skeleton from west Lake Turkana, Kenya. Nature 3I6, 788-92.

Brugal, J. P., \& J. Jaubert, I996. Stratégie d'exploitation et mode de vie des populations du Paléolithique moyen: Exemples des sites du sud de la France, in La Vie Préhistorique, ed. J.-P. Mohen. Paris: Faton, I48-55.

Carbonell, E. \& M. Mosquera, 2006. The emergence of a symbolic behaviour: The sepulchral pit of Sima de los Huesos, Sierra de Atapuerca, Burgos, Spain. Compte-Rendus Palevol $5, \mathrm{I} 55-60$.

Carretero, J-M., L. Rodríguez, R. García-González, J.-L. Arsuaga, A. Gómez-Olivencia, C. Lorenzo, A. Bonmatí, A. Gracia, I. Martínez \& R. Quam, 20I2. Stature estimation from complete long bones in the Middle Pleistocene humans from the Sima de los Huesos, Sierra de Atapuerca (Spain). Journal of Human Evolution 62, 242-55.

Defleur, A., I993. Les sépultures moustériennes. Paris: CNRS.

d'Errico, F., Ch. Henshilwood, G. Lawson, M. Vanhaeren, A.-M.Tillier, M. Soressi, F. Bresson, B. Maureille, A. Nowell, J. Lakarra, L. Backwell \& M. Julien, 2003. Archaeological evidence for the emergence of language, symbolism, and music - an alternative multidisciplinary perspective. Journal of World Prehistory I7, I-70.

Duarte, C., I998. Necrópole neolítica do Algar do Bom Santo: Contexto cronológico e espaço funerário. Revista Portuguesa de Arqueologia I (2), I07-I8.

Einwögerer, Th., H. Friesinger, M. Händel, C. Neugebauer-Maresch, U. Simon \& M. Teschler-Nicola, 
2006. Upper Palaeolithic infant burials: Decorations on the bodies of newborns indicate that they were probably important in their community. Nature 444, 285 .

Fernández-Jalvo, Y. \& P. Andrews, 200i. Atapuerca, le conte de deux sites. L'anthropologie IOS (2), 223-36.

Fleagle, J. G., Z. Assefa, F. Brown \& J. J. Shea, 2008. Paleoanthropology of the Kibish Formation, southern Ethiopia: Introduction. Journal of Human Evolution 55, 360-5.

García, N. \& J.-L.Arsuaga, 20II. The Sima de los Huesos (Burgos, northern Spain): Palaeoenvironment and habitats of Homo heidelbergensis during the Middle Pleistocene. Quaternary Science Reviews 30, I4I3-I9.

García, N., J.-L. Arsuaga \& T. Torres, 1997. The carnivore remains from the Sima de los Huesos Middle Pleistocene site (Sierra de Atapuerca, Spain). Journal of Human Evolution 33, I55-74.

Gargett, R., 1989. The evidence for Neandertal burial. Current Anthropology 30, 339-4I.

I999. Middle Palaeolithic burial is not a dead issue: The view from Qafzeh, Saint-Césaire, Kebara, Amud, and Dederiyeh. Journal of Human Evolution 37, 27-90.

Gilman, A., I984. Explaining the Upper Palaeolithic Revolution, in Marxist Perspectives in Archaeology, ed. M. Spriggs. Cambridge: Cambridge University Press, II5-26.

Henry-Gambier, D., B. Maureille \& R. White, 2004.Vestiges humains des niveaux de l'Aurignacien ancien du site de Brassempouy (Landes). Bulletins et Mémoires de la Société d'Anthropologie de Paris, n.s., I6 (I-2), 49-87.

Leroi-Gourhan,A., I964. Les religions de la Préhistoire. Paris: Presses Universitaires de France.

Martinón-Torres, M., J. M. Bermúdez de Castro, A. Gómez-Robles, L. Prado-Simón \& J.-L. Arsuaga, 2012. Morphological description and comparison of the dental remains from Atapuerca-Sima de los Huesos site (Spain). Journal of Human Evolution 62, 7-58.

McCown, T. D. \& A. Keith, I939. The Stone Age of Mount Carmel. Vol.2. The Fossil Human Remains from the Levalloiso-Mousterian. Oxford: Clarendon Press.

Orschiedt, J., 2008. Der Fall Krapina - neue Ergebnisse zur Frage von Kannibalismus beim Neandertaler. Quartär 55, 63-8I.

Pettitt, P. B., 20II. The Palaeolithic Origins of Human Burial. Oxford: Routledge.

Rendu, W., C. Beauval, I. Crevecoeur, P. Bayle, Th. Bismuth, L. Bourguignon, G. Delfour, J.-Ph. Faivre, F. Lacrampe-Cuyaubère, C. Tavormina, D. Todisco, A. Turq \& B. Maureille, 20I4. Evidence supporting an intentional Neandertal burial at La Chapelle-aux-Saints. Proceedings of the National Academy of Sciences USA III, 8I-6.

Renfrew, C., I996. The sapient behaviour paradox: How to test for potential? in Modelling the Early Human Mind, eds. P. Mellars \& K. Gibson. Cambridge: McDonald Institute for Archaeological Research, II-I5.

Russell, M. D., I987. Mortuary practice at the Krapina Neanderthal site. American Journal of Physical Anthropology 72, $38 \mathrm{I}-97$.

Sandgathe, D. M., H. L. Dibble, P. Goldberg \& S. P. McPherron, 20II. The Roc de Marsal Neandertal child: A reassessment of its status as a deliberate burial. Journal of Human Evolution 6I, 243-53.

Schmitz, R.W. (ed.), 2006. Neanderthal 1856-2006. Mainz: Philipp von Zabern.

Scott, K., I980. Two hunting episodes of Middle Paleolithic Age at La Cotte Saint-Brelade, Jersey (Channel Islands). World Archeology I2, I37-52.

Teschler-Nicola, M. (ed.), 2006. Early Modern Humans at the Moravian Gate: The Mladec Caves and Their Remains. Wien: Springer-Verlag.

Trinkaus, E., I985. Cannibalism and burial at Krapina. Journal of Human Evolution I4, 203-I6.

I995. Neandertal mortality patterns. Journal of Archaeological Science 22, I2 I-42.

20II. Late Pleistocene adult mortality patterns and modern human establishment. Proceedings of the National Academy of Sciences USA I08 (4), I267-7I.

Trinkaus, E., S. Constantin \& J. Zilhão (eds.), 20I3. Life and Death at the Peştera cu Oase: A Setting for Modern Human Emergence in Europe. Oxford: Oxford University Press.

Trinkaus, E., F. H. Smith, T. C. Stockton \& L. L. Shackelford, 2006. The human postcranial remains from Mladeč, in Early Modern Humans at the Moravian Gate: The Mladeč Caves and Their Remains, ed. M. Teschler-Nicola. Wien: Springer-Verlag, $385-445$.

Vacca, E. \& V. Pesce Delfino, 2004. Three-dimensional topographic survey of the human remains in Lamalunga Cave (Altamura, Bari, Southern Italy). Collegium Antropologicum 28 (I), II3-I9.

White, T. D., B. Asfaw, D. Degusta, H. Gilbert, G. D. Richards, G. Suwa \& F. Clark Howell, 2003. Pleistocene Homo sapiens from Middle Awash, Ethiopia. Nature 423, 742-7.

Wolpoff, M., 2002. Human Palaeontology. Ann Arbor: University of Michigan.

Zilhão, J., 2005. Burial evidence for the social differentiation of age classes in the Early Upper Palaeolithic, in Comportements des hommes du Paléolithique moyen et supérieur en Europe: Territoires et milieux. Actes du Colloque du GDR 1945 du CNRS, Paris, 8-10 janvier 2003, eds. D. Vialou, J. Renault-Miskosky \& M. Patou-Mathis. Liège: Université de Liège, 23I-4I.

2007. The emergence of ornaments and art: An archaeological perspective on the origins of behavioural 'modernity'. Journal of Archaeological Research I5, I-54.

Zilhão, J. \& E. Trinkaus, 2002. Social implications, in Portrait of the Artist as a Child: The Gravettian Human Skeleton from the Abrigo do Lagar Velho and Its Archaeological Context, eds. J. Zilhão \& E. Trinkaus. Lisboa: Instituto Português de Arqueologia, 5I9-4I.

Zilhão, J., E. Trinkaus, E., S. Constantin, Ş. Milota, M. Gherase, L. Sarcina, A. Danciu, H. Rougier, J. Quilès \& R. Rodrigo, 2007. The Peştera cu Oase people, Europe's earliest modern humans, in Rethinking the Human Revolution, eds. P. Mellars, K. Boyle, O. Bar-Yosef \& C. Stringer. Cambridge: McDonald Institute for Archaeological Research, 249-62. 